\title{
A Correlation Study between the Attitudes of the Students' towards Mathematics with their Performance in Mathematics
}

\author{
Ram Chandra Ghimire \\ ramchandraghimire17@gmail.com \\ Reader \\ Central Department of Education, T.U., Kirtipur
}

\begin{abstract}
The present study was conducted with an objective to identify the relation between the attitudes of students towards mathematics with their performance in mathematics. Based on the survey research design, the study was conducted in a sample of 154 ten grader students. The performances of the students in mathematics were obtained by the school administration whereas their attitudes towards mathematics were determined with the help of survey form entitled 'Fennema-Sherman Mathematics Attitude Scale'. The survey form was divided into eight categories as attitudes towards success in mathematics, confidence in learning mathematics, mathematics anxiety, motivation in learning mathematics, teacher scale, parents scale, mathematics usefulness and mathematics as a male domain. The study concluded with the positive correlation between the performances of the students with their attitudes towards mathematics.
\end{abstract}

Keywords: Correlation, Measuring Attitude, Comparing Performance

\section{Background}

The academic performance of the students is based on various affecting factors among such their own attitude and interest to the subject is the most hidden factor for their performance in that subject (Afe, 2001). But we as a teacher, in most of the cases,are not being motivated to raise our students' interest rather we just motivating to our students to act as a passive receiver of the knowledge without their active involvement in the learning process. And, the degree of active involvement in the learning process in more or less related to their attitudes toward the subjects which somehow indicate the outcome of the overall learning process. In this context, the present study is oriented to explore the relationship between students' attitudes towards mathematics with their performances.

\section{Statement of the problem}

The rate of involvement of students in mathematics is declining day by day in school level as well as in higher level. On the other hand, the rate of failure in mathematics is also being increased continuously(NASA, 2015). Also at the same time, student's engagement on learning 
activities could not be raised as expected. As far as I experienced, the active engagement of the students is directly associated with performance of the students (Gunuc, 2015).And, to make students actively participated on the learning activities, they need to be interested to the content that they are going to be taught (Bolhuis \&Voeten, 2004).As many researchers and educators claim that the performance of the students is result of student's own beliefs and attitudes towards the subject (Schenkel, 2009). Thompson (1992) explores that attitude held by the students will have a deep cause on the way they learn and their performance but on the contrary, in most of the cases in Nepali context, we (mathematics teacher) just enforced to categories our student as a poor performer or good performer in terms of the score student obtained in the test (Shrestha,...) but we (teachers)rarely motivated to think on the perception of the students regarding math teaching and learning which largely contributes for resulting the better performance. In this regard, the prime concern of the study is to explore the relationship between the attitudes of the students towards mathematics with their performance in mathematics in the context of Nepal.

\section{Objectives}

The objective of the study was to explore the relationship between the attitudes of the students in mathematics with their performance.

\section{Hypothesis}

There is no relationship between performance and attitudes of the students in mathematics.

\section{Literature Review}

\section{Meaning and Definition of Attitudes}

Attitude is a psychological tendency that is expressed by evaluating a particular entity with some degree of favor or disfavor (Eagly \& Chaiken, 1993). Attitude influences an individual's choice of action, and responses to challenges, incentives, and rewards (Business Dictionary). An attitude is a complex of feelings, desires, fears, convictions or other tendencies that have given a set or readiness to act (Chave, 1928).

From the above definition of attitudes, simply it can be supposed as the one's personal psychological tendency as beliefs, feelings, desire, convention, learned experience, fear which support the individual to evaluate a certain object or entity or the situation with some degree of positive or negative, favor or disfavor to respond. Ma and Kishor (1997) defined attitude towards Mathematics as "an aggregated measure of a liking or disliking of Mathematics, a tendency to engage in or avoid mathematical activities, a belief that one is good or bad at Mathematics, and a belief that Mathematics is useful or useless" (p. 27).

\section{Attitudes towards Mathematics and Performance}

Tapia \& Marsh (2004) has suggested the structure of attitudes among students toward Mathematics in four subgroups as self-confidence, value, enjoyment, and motivation these variables helps us to decide the meaning of attitudes towards mathematics refers to the psychological attachment with mathematics that somehow regulate the student's success in mathematics (Seaton et al., 2014). Based on the findings of many research studies, attitudeof students in mathematics is enough related to their performance in mathematics (Lipnevich et al., 2012; Moenikia \& Zahed-Babelan, 
2010). Among many variables affecting the attitudes of the students towards mathematics, four of them are found significant as parental influences (Mahamood et al., 2012), teachers' support (Sakiz et al., 2012), instructional practices (Bakar et al., 2010) and opportunities to learn (Yaratan \& Kasapo 2012). And, in the same way, among many variables affecting the learning performance of the students in mathematics, attitude towards mathematics is significant (Singh \& Imam, 2013).

\section{Attitude Formation}

According to Oskamp (1991), the term attitude formation refers to the movement we make from having no attitude toward an on object to having some positive or negative attitude toward that object (as sited in Bordens and Horowitz, 2002, p.167). In their introductory book of Social Psychology (2002), they acknowledge four mechanism of attitude formation as follows:

i. Mere Exposure: By being exposed to an object increases feelings, usually positive, toward that object, repeated exposure can lead to attitudes.

ii. Direct Experience: Attitudes acquired through direct experience are likely to be strongly held and to affect behavior. People are also more likely to search for information to support such attitudes.

iii. Operant \& Classical Conditioning: Most social psychologists would agree that the bulk of the attitudes are learned. That is, attitudes result from experience not by genetic inheritances.

- Operant conditioning (is) a method by which attitudes are acquired by rewarding a person for a given attitude in the hopes it will be maintained or strengthened.

- Classical Conditioning (is) a form of learning that occurs when a stimulus comes to summons a response that it is previously did not evoke to form an attitude.

iv. Observational Learning: Attitude-formation through watching what people do and whether they are rewarded or punished. Then, it supports for imitating that behavior.

v. As a natural process, the formation of attitudes is inevitable. Smith and Mackie (2000) state that, we develop attitudes as because they are useful to us.

\section{Fennema-Sherman Mathematics Attitude Scale}

Fennema-Sherman Mathematics Attitude Scale (1996) is widely used survey questionnaire form to the attitudes of the students towards mathematics. This scale defines the way of determining the attitude of the students under the following eight subheadings which covers many significant areas for understanding the image of the students towards mathematics:

\begin{tabular}{lll}
\hline S.N. & Scale & Definitions \\
\hline 1. & $\begin{array}{l}\text { Attitude Toward Success in } \\
\text { Mathematics }\end{array}$ & $\begin{array}{l}\text { The degree to which students anticipate positive } \\
\text { or negative consequences as a result of success in } \\
\text { mathematics }\end{array}$ \\
\hline 2. & Confidence in Learning & $\begin{array}{l}\text { The level of confidence in one's ability to learn and to } \\
\text { perform well on mathematical tasks. . Not intended to } \\
\text { Mathematics }\end{array}$ \\
& measure anxiety, confusion, interest or enjoyment \\
\hline
\end{tabular}




\begin{tabular}{|c|c|c|}
\hline 3. & Mathematics Anxiety & $\begin{array}{l}\text { Measures feelings of anxiety, dread, nervousness and } \\
\text { associated bodily symptoms related to doing mathematics. } \\
\text { Not intended to measure confidence or enjoyment of } \\
\text { mathematics }\end{array}$ \\
\hline 4. & Mathematics & $\begin{array}{l}\text { Measures as applied to measure and ranges from lack } \\
\text { of involvement to active enjoyment and seeking of } \\
\text { challenges. Not intended to measure interest or enjoyment } \\
\text { of mathematics. }\end{array}$ \\
\hline 5. & Teacher Scale & $\begin{array}{l}\text { The student's perception of his/her teacher's attitudes } \\
\text { toward them as learners of mathematics. }\end{array}$ \\
\hline 6. & Pare & $\begin{array}{l}\text { The student's perception of his/her mother's/father's } \\
\text { interest, encouragement and confidence in the student's } \\
\text { ability }\end{array}$ \\
\hline 7. & $\begin{array}{l}\text { Mathematics } \\
\text { Usefulness }\end{array}$ & $\begin{array}{l}\text { Student beliefs about the usefulness of mathematics } \\
\text { currently and in relationship to their future. }\end{array}$ \\
\hline 8. & $\begin{array}{l}\text { Mathematics as a Male } \\
\text { Domain }\end{array}$ & $\begin{array}{l}\text { The degree to which students see mathematics as a male, } \\
\text { female or neutral domain }\end{array}$ \\
\hline
\end{tabular}

The present study was conducted with the help of theabove-mentioned subscales as suggested by Fennema and Sherman (1996) so as to determine the attitude of the students toward mathematics.

The study conducted by Tinio (2009) with an objective to measure academic achievement in mathematics and to compare the achievement of the students on the basis of their attitudes. The researcher concluded that all three subscales (behavioral, emotional, and cognitive) are necessary to measure academic engagement. Levels of academic achievement are based on cognitive behavioral and emotional abilities. With these regards, it is also found necessary to determine the role of attitudes towards mathematics for achieving better performance in mathematics in the context of Nepal, the present study is performed.

\section{Research Design}

The study was conducted within the framework of survey research design with 154 ten grader students through simple random sampling from the sampled schools consisting around 1025 students from Kirtipur municipality.

\section{Data collection tools}

Fennema-Sherman Mathematics Attitude Scale' (Fennema \& Sherman, 1996) was used to determine the attitude of the students towards mathematics which consists 48 statements. As this survey questionnaire form was considered as standardized tools for determining the attitudes of the high school students' towards mathematics, it has been used for the collecting the information from the sampled students. The attitude scale was categorized into eight subheadings as attitudes towards success in mathematics, confidence in learning mathematics, mathematics anxiety, motivation in Mathematics, Teacher scale, parents scale, mathematics usefulness and 
mathematics as a male domain. And, the performances of the students were determined by the final test score of the sampled students from the school administration.

\section{Data collection and Analysis Process}

A survey form entailed 'Fennema-Sherman Mathematics Attitude Scale' was distributed to the sampled students with an objective to determine the attitudes of the students in mathematics. The performances of the students were determined by the final test score of the sampled students from the school administration. The relation between attitude towards mathematics and performance of the students were determined with the help of correlation analysis between the major variables involved in the survey form and test score of the students.

\section{Data Analysis, Interpretation and Discussion}

As the prime concern of the study was to determine the correlation between attitudes of the students towards mathematics with their performances in mathematics, and as there are eight subscales in the attitude scale, the correlation between each subscales and performance are presented below:

\section{Correlation between 'attitudes toward success in mathematics' and performances}

The following table presents the correlation between the attitudes of the students towards success in mathematics with their performances:

\section{Table I}

Correlation between 'attitudes toward success in mathematics' and performances

\begin{tabular}{|ll|r|r|}
\hline & & $\begin{array}{c}\text { Attitudes toward success } \\
\text { in mathematics }\end{array}$ & \multicolumn{1}{|c|}{ Performance } \\
\hline \multirow{2}{*}{$\begin{array}{l}\text { Attitudes toward success } \\
\text { in mathematics }\end{array}$} & Pearson Correlation & 1 & $.812^{* *}$ \\
\cline { 2 - 4 } & Sig. (2-tailed) & 154 & .00 \\
\cline { 2 - 5 } & $\mathrm{N}$ & $.812^{* *}$ & 154 \\
\hline Performance & Pearson Correlation & .00 & 1 \\
\hline & Sig. (2-tailed) & 154 & 154 \\
\hline
\end{tabular}

**. Correlation is significant at the 0.01 level (2-tailed).

The table shows that the value of correlation coefficient between the attitudes of students towards success in mathematics with their performance in mathematics is 0.812 , which is significant at 0.01 level of significance. This refers that the variable 'attitudes towards success in mathematics' and 'performance in mathematics' is high degree positively correlated which suggest us to conclude that the students who feel themselves success in mathematics have comparatively better performance in mathematics, the same kind of findings was also obtained by (Seaton et al., 2014).

\section{Correlation between 'confidence in learning mathematics' and performances}

The following table presents the correlation between the attitudes of the students towards confidence in learning mathematics with their performances: 
Table II

Correlation between 'confidence in learning mathematics' and performances

\begin{tabular}{|ll|r|r|}
\hline & & \multicolumn{1}{|c|}{$\begin{array}{c}\text { Confidence in learning } \\
\text { mathematics }\end{array}$} & \multicolumn{1}{|c|}{ Performance } \\
\hline $\begin{array}{l}\text { Confidence in learning } \\
\text { mathematics }\end{array}$ & Pearson Correlation & 1 & $.902^{* *}$ \\
\cline { 2 - 5 } & Sig. (2-tailed) & 154 & .00 \\
\cline { 2 - 5 } & $\mathrm{N}$ & $.902^{* *}$ & 154 \\
\hline Performance & Pearson Correlation & .00 & 1 \\
\hline & Sig. (2-tailed) & 154 & 154 \\
\hline
\end{tabular}

**. Correlation is significant at the 0.01 level (2-tailed).

The table shows that the value of correlation coefficient between the attitudes of students towards Confidence in learning mathematics with their performance in mathematics is 0.902 , which is significant at 0.01 level of significance. This refers that the variable attitudes towards confidence in learning mathematics and performance in mathematics are high degree positively correlated which suggest us to conclude that as found by (Pinxten et.al., 2014)the students who feel themselves confidences in learning mathematics have comparatively better performance in mathematics.

\section{Correlation between 'mathematics anxiety' and performances}

The following table presents the correlation between the attitudes of the students' regarding anxiety in mathematics with their performances:

Table III

Correlation between 'mathematics anxiety' and performances

\begin{tabular}{|ll|r|r|}
\hline & & mathematics anxiety & Performance \\
\hline mathematics anxiety & Pearson Correlation & 1 & $-.612^{* *}$ \\
\cline { 2 - 4 } & Sig. (2-tailed) & 154 & .00 \\
\cline { 2 - 4 } & $\mathrm{N}$ & $-.612^{* *}$ & 154 \\
\hline Performance & Pearson Correlation & .00 & 1 \\
\hline & Sig. (2-tailed) & 154 & 154 \\
\hline
\end{tabular}

**. Correlation is significant at the 0.01 level (2-tailed).

The table shows that the value of correlation coefficient between the attitudes of students towards mathematics anxiety with their performance in mathematics is -0.612 , which is significant at 0.01 level of significance. This refers that the variable attitudes towards mathematics anxiety and performance in mathematics are high degree negatively correlated as found by (Wu, 2014)which advise us to conclude that higher the level of mathematical anxiety indicate the low performance in mathematics and vice versa (Beilock \& Willingham, 2014). 


\section{Correlation between 'Motivation in Mathematics' and performances}

The following table presents the correlation between the attitudes of the students towards motivation in mathematics with their performances:

Table IV

Correlation between 'Motivation in Mathematics' and performances

\begin{tabular}{|c|c|c|c|}
\hline & & $\begin{array}{l}\text { Motivation in } \\
\text { Mathematics }\end{array}$ & Performance \\
\hline Motivation in & Pearson Correlation & 1 & $.772^{* *}$ \\
\hline \multirow[t]{2}{*}{ Mathematics } & Sig. (2-tailed) & & .00 \\
\hline & $\overline{\mathrm{N}}$ & 154 & 154 \\
\hline \multirow[t]{3}{*}{ Performance } & Pearson Correlation & $.772^{* *}$ & 1 \\
\hline & Sig. (2-tailed) & .00 & \\
\hline & $\mathrm{N}$ & 154 & 154 \\
\hline
\end{tabular}

**. Correlation is significant at the 0.01 level (2-tailed).

The table shows that the value of correlation coefficient between the attitudes of students towards 'Motivation in Mathematics' with their performance in mathematics is .772, which is significant at 0.01 level of significance. This refers that the variable 'Motivation in Mathematics' and performance in mathematics are high degree positively correlated (Hooper et al. 2017) which suggest us to conclude that students who are motivated learning mathematics have higher chance of higher performance in mathematics.

\section{Correlation between 'Teacher Scale' and performances}

The following table presents the correlation between the attitudes of the students towards Teacher Scale with their performances:

Table V

Correlation between 'Teacher Scale' and performances

\begin{tabular}{|ll|r|r|}
\hline & & Teacher Scale & Performance \\
\hline Teacher Scale & Pearson Correlation & 1 & $.692^{* *}$ \\
\cline { 2 - 4 } & Sig. (2-tailed) & 154 & .00 \\
\cline { 2 - 4 } & $\mathrm{N}$ & $.692^{* *}$ & 154 \\
\hline Performance & Pearson Correlation & .00 & 1 \\
\hline & Sig. (2-tailed) & 154 & 154 \\
\hline
\end{tabular}

**. Correlation is significant at the 0.01 level (2-tailed).

The table shows that the value of correlation coefficient between the attitudes of students towards 'Teacher Scale' with their performance in mathematics is .692, which is significant at 0.01 level of significance. The score supports the finding of Shuls \& Trivitt (2015) as the variable 'Teacher Scale' and performance in mathematics are high degree positively correlated which suggest us to conclude that students with positive attitude with their teacher tend to have better performance in mathematics. 


\section{Correlation between 'parents scale' and performances}

The following table presents the correlation between the attitudes of the students towards parents scale with their performances:

Table VI

Correlation between 'Parents Scale' and performances

\begin{tabular}{|ll|r|r|}
\hline & & Parents scale & Performance \\
\hline Parents scale & Pearson Correlation & 1 & $.210^{* *}$ \\
\cline { 2 - 4 } & Sig. (2-tailed) & 154 & .00 \\
\cline { 2 - 4 } & $\mathrm{N}$ & $.210^{* *}$ & 154 \\
\hline Performance & Pearson Correlation & .00 & 1 \\
\hline & Sig. (2-tailed) & 154 & 154 \\
\hline
\end{tabular}

**. Correlation is significant at the 0.01 level (2-tailed).

The table shows that the value of correlation coefficient between the attitudes of students towards 'parents scale' with their performance in mathematics is .210 , which is significant at 0.01 level of significance. This refers that the variable 'Parents Scale' and performance in mathematics are low degree positively correlated which suggest us to conclude that the student's perception of his/her mother's/father's interest, encouragement and confidence in the student's ability is less related with the performance of student in mathematicsas obtained by Leander and Fabella (2020).

\section{Correlation between 'Mathematics Usefulness scale' and performances}

The following table presents the correlation between the attitudes of the students towards Mathematics usefulness scale with their performances:

Table VII

Correlation between 'Mathematics Usefulness scale'and performances

\begin{tabular}{|ll|r|r|}
\hline & & $\begin{array}{r}\text { Mathematics Usefulness } \\
\text { scale }\end{array}$ & \multicolumn{1}{|c|}{ Performance } \\
\hline \multirow{2}{*}{$\begin{array}{l}\text { Mathematics Usefulness } \\
\text { scale }\end{array}$} & Pearson Correlation & 1 & $.590^{* *}$ \\
\cline { 2 - 5 } & Sig. (2-tailed) & 154 & .00 \\
\cline { 2 - 5 } Performance & $\mathrm{N}$ & $.590^{* *}$ & 154 \\
\hline & Pearson Correlation & .00 & 1 \\
\hline & Sig. (2-tailed) & 154 & 154 \\
\hline
\end{tabular}

**. Correlation is significant at the 0.01 level (2-tailed).

The table shows that the value of correlation coefficient between the attitudes of students towards 'Mathematics Usefulness Scale' with their performance in mathematics is .590, which is significant at 0.01 level of significance. This refers that the variable 'Mathematics Usefulness Scale' and performance in mathematics are moderately correlated which suggest us to conclude 
that the student beliefs about the usefulness of mathematics currently and in relationship to their future affect their performance in mathematicsas found by (Singh, 2002).

\section{Correlation between 'Mathematics as a Male Domain Scale' and performances}

The following table presents the correlation between the attitudes of the students towards Mathematics as a male domain scale with their performances:

Table VIII

Correlation between 'mathematics as a male domain scale' and performances

\begin{tabular}{|ll|r|r|}
\hline & & $\begin{array}{c}\text { Mathematics as a Male } \\
\text { Domain Scale }\end{array}$ & \multicolumn{1}{c|}{ Performance } \\
\hline \multirow{2}{*}{$\begin{array}{l}\text { Mathematics as a Male } \\
\text { Domain Scale }\end{array}$} & Pearson Correlation & 1 & $.102^{* *}$ \\
\cline { 2 - 4 } & Sig. (2-tailed) & 154 & .00 \\
\cline { 2 - 4 } & $\mathrm{N}$ & $.102^{* *}$ & 154 \\
\hline Performance & Pearson Correlation & .00 & 1 \\
\hline & Sig. (2-tailed) & 154 & 154 \\
\hline
\end{tabular}

**. Correlation is significant at the 0.01 level (2-tailed).

The table shows that the value of correlation coefficient between the attitudes of students towards 'Mathematics as a Male Domain Scale' with their performance in mathematics is .102, This refers that the variable 'Mathematics as a Male Domain Scale' and performance in mathematics are positively correlated which suggest us to conclude that the degree to which students see mathematics as a male, female or neutral domain very rarely affect to the performance of the students in mathematics which contradict the findings of Cox (2010) as female seems to have poor performance in comparison with male students.

\section{Correlation between Attitude towards mathematics and performance}

The following table presents the correlation between the attitudes of the students towards mathematics with their performances:

Table IX

Correlation between attitudes and performances

\begin{tabular}{|ll|r|r|}
\hline & & Attitudes & Performance \\
\hline \multirow{4}{*}{ Attitudes } & Pearson Correlation & 1 & $.872^{* *}$ \\
\cline { 2 - 4 } & Sig. (2-tailed) & 154 & .00 \\
\cline { 2 - 4 } & $\mathrm{N}$ & $.872^{* *}$ & 154 \\
\hline Performance & Pearson Correlation & .00 & 1 \\
\hline & Sig. (2-tailed) & 154 & 154 \\
\hline
\end{tabular}

**. Correlation is significant at the 0.01 level (2-tailed).

The table shows that the value of correlation coefficient between the attitudes of students towards mathematics with their performance in mathematics is .872 , This refers that the attitudes of 
the students towards mathematics and performance in mathematics are high degree positively correlated which suggest us to conclude that the students with positive attitudes may have chance of having better performance in mathematics.

The findings of the study are matched with the findings of the study done by Barry (2005) as he concluded different physical and psychological factors related with students and parents have a direct impact in the score of the students in mathematics. The finding of the study done by Puckett (2012) also supports to the findings of the present study as the positive teacherstudent relationship may cause for developing the positive attitudes among students towards mathematics and lead students towards the better performance in mathematics. Tinio (2009) also viewed that student's behavioral, emotional, and cognitive levels determine the attitudes and the academic performance.

\section{Conclusion}

With reference to the finding and discussion mentioned above, it can be concluded that the attitudes of students towards mathematics is directly related to the performance of the students in mathematics which means what sorts of attitudes do the students holds towards mathematics clearly reflects their performance in mathematics. So, for the better teaching learning outcomes in mathematics, first it is necessary to have positive attitudes towards mathematics among students. Therefore, we as a teacher of mathematics need to develop psychological attachment with mathematics among students for meaningful learning which results for the better performance in mathematics among students.

\section{Implications}

The present study is implacable in many ways. The first implication of the study is directly related to the mathematics teachers as this study encourages teachers for developing positive attitudes among students towards mathematics for the better learning outcomes. Second, this study is implacable to the policy persons for implementing different motivation awareness and remedial programme to the students for creating positive attitudes among them to achieve the desired learning outcomes.

\section{References}

Afe, J. ( 2001). Reflections on Becoming a Teacher and the Challenges of Teacher Education. Inaugural Lecture Series. Benin City: University of Benin, Nigeria

Barry, J. (2005). The effect of socio-impact status on academic achievement. Master's Thesis, Wichita State University, Department of Sociology, Wichita.

Bolhuis, S. and Voeten, J. M. (2004). Teachers' conception of student learning and own learning. Teachers and teaching, Theory and Practice, 10(1), 77-98.

Bordens, K. S., \& Horowitz, I. A. (2002). Social psychology (2nd ed.). Lawrence Erlbaum Associates Publishers.

Chave, E. J. 1928. A new type scale for measuring attitudes. Relig. Educ., 23, 364-369. 
Eagly, A. H., \& Chaiken, S. (1993). The psychology of attitudes. Harcourt Brace Jovanovich College Publishers.

Fennema, E. \& Sherman, J. A. (1996). Fennema-Sherman Mathematics Attitude Scale. Vol-6 (1).

Gunuc, S. (2014). The Relationship Between Student Engagement and Their Academic Achievement. International Journal on New Trends in Education and Their Implications, $5(4)$.

K. Singh, M. Granville, and S. Dika, "Mathematics and science achievement: effects of motivation, interest, and academic engagement," Journal of Educational Research, vol. 95, no. 6, pp. 323-332, 2002.

Leander, V. \& Fabella J. (2020).Parental Involvement and Academic Performances of Grade 7 Students. Available at: SSRN: https://ssrn.com/abstract=3630178 or http://dx.doi. org/10.2139/ssrn.3630178

Lipnevich, A. A., Maccann, C., Krumm, S., Burrus, J., \& Roberts, R. D. (2011). Mathematics attitudes and mathematics outcomes of U.S. and Belarusian middle school students. Journal of Educational Psychology, 103(1), 105-118. doi:10.1037/a0021949

Ma, X., \& Kishor, N. (1997). Assessing the Relationship Between Attitude Toward Mathematics and Achievement in Mathematics: A Meta-Analysis. Journal for Research in Mathematics Education, 28 (1), 26-47.

Mahamood, S. F., Tapsir, R., Saat, A., Ahmad, S., Wahab, K. A., Boon, M. H. A., \& Rahman, K. A. (2012). Parental attitude and involvement in children's education: A study on the parental aspiration among form four students in Selangor. Procedia - Social and Behavioral Sciences, 42), 117-130. doi:10.1016/j.sbspro.2012.04.173

Moenikia, M., \& Zahed-Babelan, A. (2010). A study of simple and multiple relations between mathematics attitude, academic motivation and intelligence quotient with mathematics achievement. Procedia-Social and Behavioral Sciences, 2, 1537-1542. doi:10.1016/j. sbspro.2010.03.231

Oskamp, S. (1991). Attitudes and opinions (2nd ed.). Prentice-Hall, Inc.

Pinxten, M., Marsh, H., DeFraine, B., Van den Noortgate, W., \& Van Damme, J. (2014). Enjoying mathematics or feeling competent in mathematics? Reciprocal effects on mathematics achievement and perceived math effort expenditure. British Journal of Educational Psychology, 84, 152-174. https://doi.org/10.1111/bjep.12028

Puckett, N. (2012). Students Motivation. Journal of Research in Mathematics Education, 11(3), 21-28.

Sakiz, G., Pape, S. J., \& Hoy, A. W. (2012). Does perceived teacher affective support matter for middle school students in mathematics classrooms? Journal of School Psychology, 50(2), 235-255. doi:10.1016/j.jsp.2011.10.005

Schenkel, B. (2009). The impact of an attitude toward mathematics-on-mathematics performance. Unpublished MA Thesis, Mariette College. 
Seaton, M., Parker, P., Marsh, H. W., Craven, R. G., \& Yeung, A. S. (2014). The reciprocal relations between self-concept, motivation, and achievement: juxtaposing academic self-concept and achievement goal orientations for mathematics success. Educational Psychology, 34(1), 49-72. https://doi.org/10.1080/01443410.2013.825232

Shuls, J. V. \& Ritter, G. W. (2013). Teacher preparation: Not an either/or. Phi Delta Kappan, 94(7), 28-32..

Singh, S. P., \& Imam, A. (2013). Effect of personal and institutional variables on mathematics achievement of secondary school students. IOSR Journal of Humanities and Social Science, 10(3), 22-33.

Smith, E. R., \& Mackie, D. M. (2000). Social psychology (2nd ed.). Psychology Press

Tapia, M. \& Marsh, G. (2004). An instrument to measure mathematics attitudes. Academic Exchange Quarterly.

Thompson, A G. (1992). Teachers' Beliefs and Conceptions: A Synthesis of the Research. In D. A. Grouws (Ed.), Handbook of Research on Mathematics Teaching and Learning, (pp. 127-146). New York: Macmillan Publishing Company.

Tinio, M.F. (2009). Academic engagement scale for grade school grade school students. The Assessment Handbook, 2, 64-75 